BACKGROUND: We have previously shown that incubation of human endothelial cells with mast cell granules results in potentiation of lipopolysaccharide-induced production of interleukin- 6 and interleukin-8.

Aims: The objective of the present study was to identify candidate molecules and signal transduction pathways involved in the synergy between mast cell granules and lipopolysaccharide on endothelial cell activation.

Methods: Human umbilical vein endothelial cells were incubated with rat mast cell granules in the presence and absence of lipopolysaccharide, and IL-6 production was quantified. The status of c-Jun aminoterminal kinase and extracellular signal-regulated kinase 1/2 activation, nuclear factor- $\mathrm{KB}$ translocation and intracellular calcium levels were determined to identify the mechanism of synergy between mast cell granules and lipopolysaccaride.

Results: Mast cell granules induced low levels of interleukin-6 production by endothelial cells, and this effect was markedly enhanced by lipopolysaccharide. The results revealed that both serine proteases and histamine present in mast cell granules were involved in this activation process. Mast cell granules increased intracellular calcium, and activated c-Jun amino-terminal kinase and extracellular signal-regulated kinase $1 / 2$. The combination of lipopolysaccharide and mast cell granules prolonged c-Jun amino-terminal kinase activity beyond the duration of induction by either stimulant alone and was entirely due to active proteases. However, both proteases and histamine contributed to calcium mobilization and extracellular signal-regulated kinase $1 / 2$ activation. The nuclear translocation of nuclear factor- $\kappa B$ proteins was of greater magnitude in endothelial cells treated with the combination of mast cell granules and lipopolysaccharide.

Conclusions: Mast cell granule serine proteases and histamine can amplify lipopolysaccharide-induced endothelial cell activation, which involves calcium mobilization, mitogen-activated protein kinase activation and nuclear factor- $\mathrm{kB}$ translocation.

Key words: Histamine, Serine protease, Lipopolysaccharide, Endothelial cells

\section{Signal transduction pathways in mast cell granule-mediated endothelial cell activation}

\author{
Luqi Chi ${ }^{1}$, Lisa Stehno-Bittel ${ }^{2}$, Irina Smirnova ${ }^{2}$, \\ Daniel J Stechschulte ${ }^{1}$ and \\ Kottarappat N. Dileepan ${ }^{\mathrm{CA}, 1}$
}

${ }^{1}$ Division of Allergy, Clinical Immunology and Rheumatology, Department of Medicine, and ${ }^{2}$ Department of Physical Therapy and Rehabilitation Sciences, University of Kansas Medical Center, 3901 Rainbow Boulevard, Kansas City, KS 66160-7317, USA

\author{
${ }^{\mathrm{CA}}$ Corresponding Author \\ Tel: + 19135883818 \\ Fax: +19135883987 \\ E-mail: kdileepan@kumc.edu
}

\section{Introduction}

Vascular endothelium functions as a selective barrier between blood and tissues, and regulates many aspects of the inflammatory and immune responses. The activation of endothelial cells, with resultant syntheses of both pro-inflammatory and anti-inflammatory mediators and the expression of adhesion molecules, is critical for immune surveillance and disease progression. ${ }^{1-4}$

Mast cells are integral constituents of the vessel wall, and their numbers are elevated in vascular diseases such as atherosclerosis. ${ }^{5-7}$ When activated, mast cells release vasoactive amines, prostaglandins, leukotrienes, cytokines, proteoglycans, and proteases that are potent modulators of endothelial cell function. ${ }^{5}$ Previous reports from our laboratory have shown that incubation of human endothelial cells with rat mast cell granules (MCG) resulted in potentiation of lipopolysaccharide (LPS)-induced interleukin (IL)-6 and IL-8 production. ${ }^{8,9}$ Further studies have shown that LPS-induced production of IL-6 by human umbilical vein endothelial cells (HUVECs) was amplified by protease-activated receptor (PAR) agonist peptides ${ }^{10}$ and histamine. ${ }^{11}$ These results indicated that at least two components of the MCG, 
proteases and histamine, participate in LPS-induced synergy of endothelial cell activation. Activation of endothelial cells by extracellular stimuli involves participation of various signal transduction pathways including intracellular $\mathrm{Ca}^{2+}$, mitogen-activated protein (MAP) kinase activity, and nuclear factor (NF)- $\kappa \mathrm{B}$ translocation. ${ }^{12-15}$ The purpose of this study was to evaluate the relative contribution of proteases and histamine in MCG-mediated endothelial cell activation, and to identify the signal transduction pathways that are involved in this process. The results presented in this report demonstrate that MCG are capable of inducing intracellular $\mathrm{Ca}^{2+}$ mobilization, activation of MAP kinases, and translocation of NF$\kappa \mathrm{B}$, and that both serine proteases and histamine present in MCG participate in the potentiation of LPSinduced endothelial cell activation.

\section{Materials and methods}

\section{Materials}

HUVECs, endothelial cell growth medium-2 with the recommended growth factors, $N$-2-hydroxyethylpiperazine- $N^{\prime}$-2-ethane-sulfonic acid, Hank's balanced salt solution, trypsin-ethylenediaminetetraacetate (EDTA), trypsin neutralizing solution, and trypsin were purchased from Clonetics (San Diego, CA, USA). Minimum Essential Medium and fetal bovine serum were purchased from Hyclone Laboratories (Logan, UT, USA). Heparin, penicillin, streptomycin, metrizamide, Escherichia coli LPS and the protease inhibitor cocktail were obtained from Sigma Chemical Co. (St Louis, MO, USA). $\gamma-\left[{ }^{32} \mathrm{P}\right]$-adenosine triphosphate (ATP) was supplied by New England Nuclear (Boston, MA, USA). The enzyme-linked immunosorbant assay (ELISA) kits for IL-6 were purchased from $\mathrm{R} \& \mathrm{D}$ systems (Minneapolis, MN, USA). Calcium crimson and Fluo-4 were purchased from Molecular Probes (Eugene, OR, USA). The NF- $\kappa \mathrm{B}-$ specific oligonucleotide and its complimentary strand were synthesized at the Biotechnology Support Facility of the University of Kansas Medical Center. Protein A/Gcoated agarose beads, glutathione- $S$-transferase (GST)-c-Jun, anti-goat and anti-mouse immunoglobulin $G$ (IgG)-horseradish peroxide, polyclonal antibodies against c-Jun amino-terminal kinase (JNK1) (C-17), extracellular signal-regulated kinase-1 (ERK)1 (C-16) and ERK2 (C-14), and monoclonal IgG against phosphorylated ERK (p-ERK), which recognizes both phosphorylated ERK1 and ERK2, were obtained from Santa Cruz (Santa Cruz, CA, USA). MAP kinase kinase (MEK) inhibitor PD98059 was purchased from Calbiochem (San Diego, CA, USA). Bradford protein assay reagents were purchased from Bio-Rad (Herculus, CA, US). Nitrocellulose membrane and western blotting detection reagents were purchased from
Amersham (Piscataway, NJ, USA). All other reagents were supplied by Fisher Scientific (Pittsburgh, PA, USA).

\section{Culture of HUVECs}

HUVECs were grown in endothelial cell growth medium-2 containing the recommended growth factors and $5 \%$ fetal bovine serum at $37^{\circ} \mathrm{C}$ in a humidified atmosphere containing $5 \% \mathrm{CO}_{2}$. The cells used in all experiments were between three and six passages.

\section{Preparation of mast cell granules}

Three-month-old to four-month-old Sprague-Dawley rats $(300-400 \mathrm{~g})$ were the source of peritoneal mast cells. The rats were euthanized using inhaled Halothane. The methods employed for the isolation of mast cells and MCG have been described previously. ${ }^{8,16}$ MCG were aliquoted and frozen at $-20^{\circ} \mathrm{C}$ until use. The concentrations of MCG used in each experiment were expressed as the equivalent of the starting mast cell number.

\section{Treatment of MCG with phenylmethylsulfonyl fluoride}

MCG were treated with medium or the serine protease inhibitor phenylmethylsulfonyl fluoride (PMSF) $(1 \mathrm{mmol} / \mathrm{l})$ for $12 \mathrm{~h}$ at $4{ }^{\circ} \mathrm{C}$, and were dialyzed against $100 \mathrm{mmol} / \mathrm{l}$ of Tris ( $\mathrm{pH} 7.5$ ) for $4 \mathrm{~h}$ with three changes of buffer.

\section{Measurement of protease activity and histamine levels in MCG}

Aliquots of PMSF-treated and control MCG preparations were analyzed for their protease activity and histamine content. The serine protease activity (chymase) in MCG preparation was assayed spectrophotometrically at $405 \mathrm{~nm}$ by monitoring the hydrolysis of succinyl-phenylalanyl-leucyl-phenylanyl- $p$-nitroanalide. The reaction was carried out at $37^{\circ} \mathrm{C}$ in $150 \mathrm{mmol} / \mathrm{l}$ of Tris ( $\mathrm{pH} 7.6$ ) in the presence of $1 \mathrm{mmol} / \mathrm{l}$ of substrate and the MCG preparation (equivalent to 0.5 million mast cells) in a final volume of $1 \mathrm{ml}$. The enzyme activity was continuously monitored and the rate of reaction was calculated using the extinction coefficient of $8800 / \mathrm{M} / \mathrm{cm}$ for $p$ nitroanalide as described elsewhere. ${ }^{17}$ Histamine content in mast cell granules was quantified using an immuno-competition assay at the IBT Reference Laboratory (Lenexa, KS, USA) using a commercially available ELISA kit. 


\section{Assay of IL-6 production}

HUVECs $(10,000)$ were added to each of the wells of a 96-well microtiter plate and allowed to adhere for $24 \mathrm{~h}$. Following adherence, activating stimuli or medium were added to the monolayers and the final volume adjusted to $0.2 \mathrm{ml}$. The cells were incubated for the indicated time periods at $37^{\circ} \mathrm{C}$ under the atmosphere of $5 \%$ humidified $\mathrm{CO}_{2}$. After the incubation, the culture supernatants were analyzed for IL-6 levels by ELISA according to the manufacturer's protocol.

\section{Determination of intracellular calcium mobilization}

HUVECs were plated on glass cover slips and allowed to grow to confluency within $48 \mathrm{~h}$. Aliquots of MCG equivalent to $3 \times 10^{5}$ mast cells were added to cover slips on which monolayers of HUVECs $(6 \times$ $\left.10^{5}\right)$ were grown. Cells were incubated with the $\mathrm{Ca}^{2+}$-sensing fluorophore, Fluo-4 $(1 \mu \mathrm{mol} / \mathrm{l})$, for 45 $\min$ at $37^{\circ} \mathrm{C}$ in $5 \% \mathrm{CO}_{2}$. Cover slips were placed in a Fluorochamber on an Olympus Fluoview 300 Confocal Microscope. Cells were illuminated with an argon laser at $488 \mathrm{~nm}$ and emitted light was detected at $510 \mathrm{~nm}$. Images were captured every 6 sec over a $10-$ min period. In additional experiments, the cells were imaged on an inverted Nikon microscope with a SPOT fluorescence sensing camera. In this case, cells were loaded with the $\mathrm{Ca}^{2+}$ indicator calcium crimson. Background images were collected from each field and digitally subtracted from the regions of interest. Images were analyzed with the Fluoview and Photoshop software, allowing mean fluorescence values to be obtained from individual cells over time. In order to normalize for variations in dye loading, the initial three fluorescence values for each cell were averaged to determine the basal fluorescence level. This value was referred to as $F_{\mathrm{o}}$. Each subsequent fluorescence value $(F)$ was divided by $F_{\mathrm{o}}$, and the $F / F_{\mathrm{O}}$ ratio provides a clear illustration of changes in $\mathrm{Ca}^{2+}$ over time. Statistical analysis of fluorescence values was completed using SigmaStat.

\section{Assay of JNK activity}

Confluent HUVEC monolayers were treated with indicated concentrations of MCG in the presence or absence of LPS at $37^{\circ} \mathrm{C}$ for selected periods of time. After incubation, the cells were lysed with Triton Lysis Buffer (TLB) containing $20 \mathrm{mmol} / 1$ of Tris ( $\mathrm{pH}$ 7.4), $137 \mathrm{mmol} / \mathrm{l}$ of $\mathrm{NaCl}, 10 \%$ (vol/vol) glycerol, $1 \%$ (vol/vol) Triton X-100, $2 \mathrm{mmol} / 1$ of EDTA, $25 \mathrm{mmol} / 1$ of $\beta$-glycerolphosphate, $2 \mathrm{mmol} / \mathrm{l}$ of sodium pyrophosphate, $1 \%(\mathrm{vol} / \mathrm{vol})$ protease inhibitor cocktail and $0.5 \mathrm{mmol} / 1$ of dithiothereitol at $4^{\circ} \mathrm{C}$ for $30 \mathrm{~min}$. Cell debris was removed by centrifugation of the lysate at $13,000 \times g$ for $10 \mathrm{~min}$. After quantification of the protein content, samples were incubated with 40 $\mu \mathrm{l}$ of protein $\mathrm{A} / \mathrm{G}$-coated agarose beads and $0.6 \mu \mathrm{g}$ of goat polyclonal antibody against JNK1 for $2 \mathrm{~h}$ at $4^{\circ} \mathrm{C}$. The beads were washed by centrifugation and resuspended in TLB buffer and, thereafter, kinase buffer $\left(25 \mathrm{mmol} / 1\right.$ of hydroxyethylpiperazine- $N^{\prime}-2$ ethane-sulfonic acid ( $\mathrm{pH} 7.5$ ), $12.5 \mathrm{mmol} / \mathrm{l}$ of $\mathrm{MgCl}_{2}$, $25 \mathrm{mmol} / \mathrm{l}$ of $\beta$-glycerolphosphate supplemented with $1 \mathrm{mmol} / \mathrm{l}$ of sodium orthovandate and 0.5 $\mathrm{mmol} / \mathrm{l}$ of dithiothereitol). Each sample was incubated with GST-c-Jun as the substrate for JNK1 in the presence of $0.1 \mathrm{mmol} / 1$ of unlabeled ATP, $5 \mu \mathrm{Ci}$ of $\gamma$ $\left.{ }^{32} \mathrm{P}\right] \mathrm{ATP}$, and kinase buffer in a volume of $20 \mu \mathrm{l}$ for 15 min at $30^{\circ} \mathrm{C}$. Thereafter, reactions were terminated by boiling in $2 \times$ sodium dodecyl sulfate (SDS) sample buffer for $5 \mathrm{~min}$. Samples were subsequently subjected to electrophoresis on 12\% SDS-polyacrylamide gel and visualized by autoradiography. Protein loads were monitored in western blot using anti-JNK1 antibody.

\section{Assay of phosphorylated ERK1/2}

Confluent HUVEC monolayers were incubated with indicated concentrations of MCG or histamine. Whenever applicable, the incubations also contained diphenhydramine and PD98059 to block H-1 receptors and MEK-1 activation, respectively. After treatment with indicated agents, the cells were lysed with TLB at $4^{\circ} \mathrm{C}$ for $30 \mathrm{~min}$. Cell debris was removed by centrifugation at $13,000 \times g$ for $10 \mathrm{~min}$. After quantification of the protein content in the supernatants, aliquots normalized for protein concentrations were mixed with equal volumes of $2 \times$ SDS sample buffer and heated to $100^{\circ} \mathrm{C}$ for $10 \mathrm{~min}$. Samples were electrophoresed on 12\% SDS-polyacrylamide gels and transferred onto a nitrocellulose filter. The filter was treated with $5 \%$ non-fat milk in phosphatebuffered saline and incubated with the antibody specific for phosphorylated ERK1/2. The reaction was detected by enhanced chemiluminescence. Protein loads were monitored by western blot using antiERK1/2 antibody.

\section{NF-KB activation and assay}

To evaluate the role of NF- $\kappa \mathrm{B}$ in MCG-mediated and LPS-mediated activation of endothelial cells, the

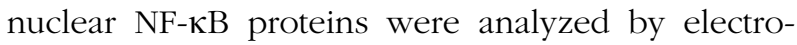
phoretic mobility shift assay (EMSA). Confluent HUVEC monolayers were treated with MCG, LPS or the combination of MCG and LPS for the indicated time intervals at $37^{\circ} \mathrm{C}$. Preparation of nuclear extracts was performed as described previously. ${ }^{18,19}$ EMSA was carried out utilizing specific oligonucleotide containing NF- $\kappa \mathrm{B}$ binding site 5'-AGTTGAGGGGACTTTCCCAGGC-3'. The specific oligonucleotide 
and its complimentary strand were annealed and then end-labeled using $\gamma-\left[{ }^{32}\right.$ P]ATP and T4-polynucleotide kinase. Nuclear protein extracts $(1 \mu \mathrm{g})$ were mixed with $3 \mu \mathrm{g}$ of poly $(\mathrm{dI}-\mathrm{dC})$.poly $(\mathrm{dI}-\mathrm{dC})$ and $2 \mathrm{ng}(100,000-400,000 \mathrm{cpm})$ of end-labeled DNA in $30 \mu \mathrm{l}$ of EMSA buffer and incubated for $30 \mathrm{~min}$ at $25^{\circ} \mathrm{C}$. The EMSA buffer for NF- $\mathrm{BB}$ consisted of 10 $\mathrm{mmol} / \mathrm{l}$ of Tris $-\mathrm{HCl}(\mathrm{pH} 7.5)$ containing $40 \mathrm{mmol} / \mathrm{l}$ of $\mathrm{NaCl}, 1 \mathrm{mmol} / \mathrm{l}$ of EDTA, $1 \mathrm{mmol} / 1$ of $\beta$-mercaptoethanol, $4 \%$ glycerol, $0.1 \% \mathrm{NP}-40$ and $15 \mu \mathrm{mol} / \mathrm{l}$ of bovine serum albumin. Following the initial binding reaction, $20 \mu \mathrm{l}$ of the mixture was electrophoresed at $150 \mathrm{~V}$ for $3 \mathrm{~h}$ at $25^{\circ} \mathrm{C}$ through a native $6 \%$ polyacrylamide gel, which was prepared in $45 \mathrm{mmol} / \mathrm{l}$ of Tris-borate buffer containing $1 \mathrm{mmol} / 1$ of EDTA. After electrophoresis, the gel was dried and processed for autoradiography.

\section{Results}

\section{Effect of MCG on LPS-induced IL-6 production by HUVECs}

The results depicted in Fig. 1 demonstrate the effects of MCG on naïve and LPS-activated HUVECs. Production of IL- 6 by HUVECs was detected as early as $2 \mathrm{~h}$ after incubation with MCG. IL-6 production gradually increased and plateaued by $8 \mathrm{~h}$, and remained unchanged throughout the remaining $48 \mathrm{~h}$. In the presence of LPS, production of IL- 6 induced by MCG was significantly amplified during the 48-h incubation period. Dialysis of MCG, which removed >99\% of histamine (9158 and $0.19 \mathrm{ng} / 10^{6}$ mast cell equivalent for control and dialyzed MCG, respectively) decreased endothelial cell IL-6 production by 40$60 \%$ either in the presence or absence of LPS. Inhibition of serine protease activity in MCG by treatment with PMSF $\left(0.72\right.$ and $0 \mathrm{U} / 10^{6}$ mast cell equivalent for control and PMSF-treated MCG, respectively) and depletion of histamine completely abolished the direct and modulating effect.

\section{Effect of MCG and LPS on $\mathrm{Ca}^{2+}$ mobilization in HUVECS}

The effect of MCG, LPS and the combination of MCG and LPS on $\mathrm{Ca}^{2+}$ mobilization in HUVECs was studied. Transient changes in free intracellular $\mathrm{Ca}^{2+}$ were measured in confluent monolayers of HUVEC using fluorescent markers. The time course and magnitude of responses for MCG, LPS and the combination are shown in Fig. 2A. The kinetics of transient changes in $\mathrm{Ca}^{2+}$ was similar for all agonists with each agonist added 2 min into the experiment. The peak transient changes in $\mathrm{Ca}^{2+}$ were plotted for each of the agonists as shown in Fig. 2B. $F / F_{\mathrm{o}}$ values for control cells bathed in media over 6 min were
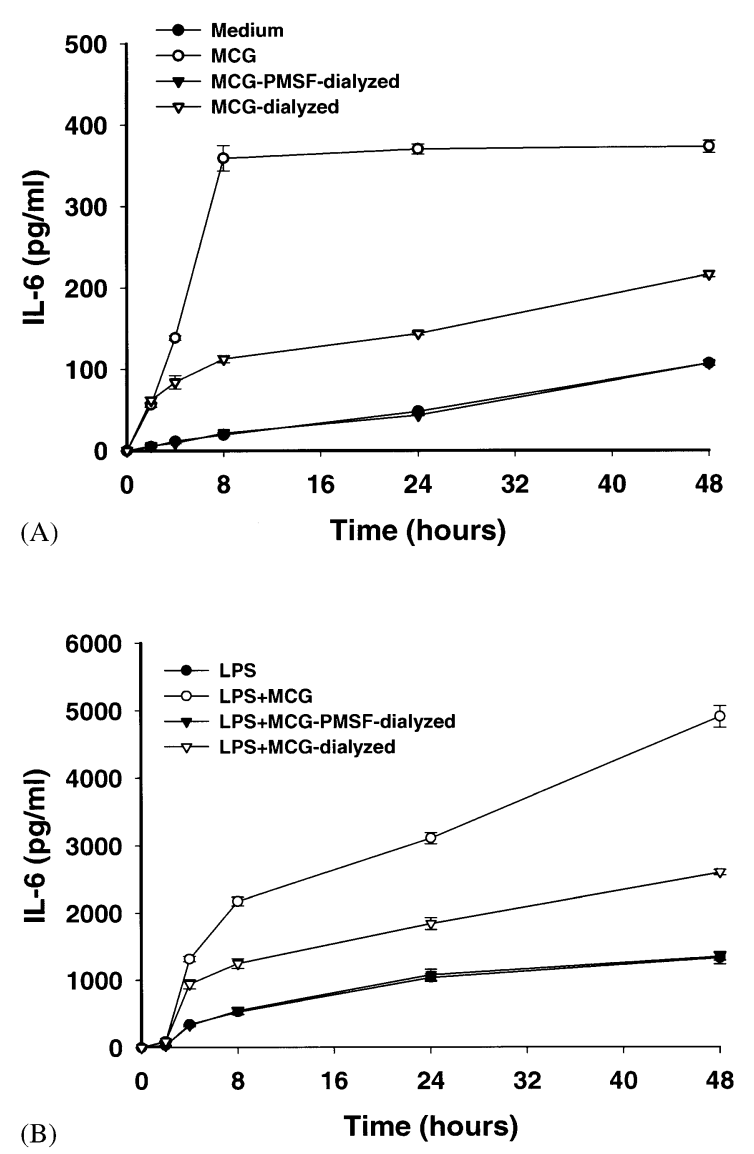

FIG. 1. Kinetics of IL-6 production by LPS-activated and MCGactivated HUVECs. HUVEC monolayers $(10,000)$ were cultured with PMSF-treated and dialyzed MCG, dialyzed MCG or intact MCG (5000 mast cell equivalents) in the absence (A) and presence (B) of $100 \mathrm{ng} / \mathrm{ml}$ of LPS for the time intervals indicated. IL-6 concentrations in the culture media were assayed by ELISA. Values are the mean \pm standard error of the mean of quadruplicate culture wells.

$0.87 \pm 0.04$ ( $n=53$ cells $)$, demonstrating the level of photobleaching that the fluorophore underwent with normal laser illumination. Exposure to LPS (100 ng/ $\mathrm{ml})$ induced a rapid increase in fluorescence indicating rising $\mathrm{Ca}^{2+}$ levels $\left(F / F_{\mathrm{O}}=1.47 \pm 0.07 ; n=78\right)$. Application of MCG caused a greater transient peaking at $2.21 \pm 0.18(n=66)$. Dialysis of MCG, which removed histamine, blunted the MCG response to $1.19 \pm 0.14(n=24)$. Inhibition of serine protease activity by treatment with PMSF and subsequent dialysis completely abrogated the effect of MCG $(0.84 \pm 0.03 ; n=16)$. The combined application of MCG and LPS caused a peak transient change that was only slightly greater than MCG alone $\left(F / F_{\mathrm{O}}=\right.$ $2.33 \pm 0.13 ; n=41)$.

\section{Effect of MCG and LPS on JNK activation in HUVECs}

Activation of JNK plays a significant role in signal transduction pathways in endothelial cells. ${ }^{20-22}$ Therefore, JNK activity was evaluated after activation 


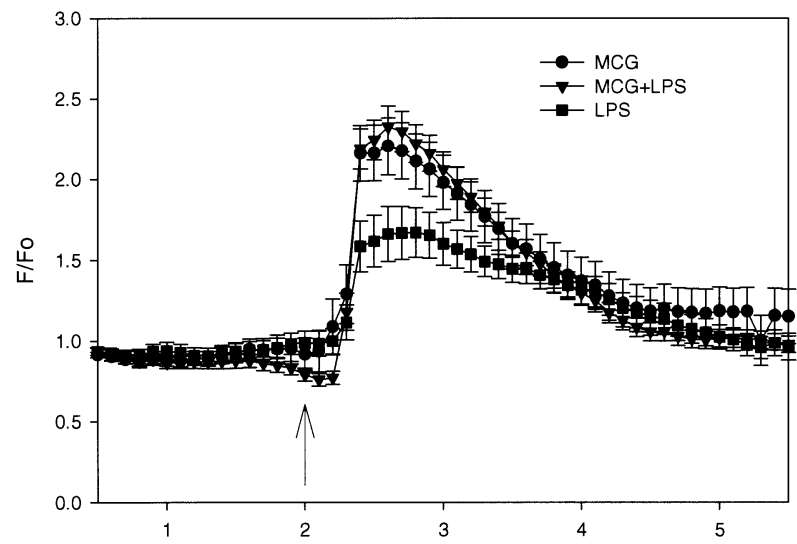

(A)

Time (minute)

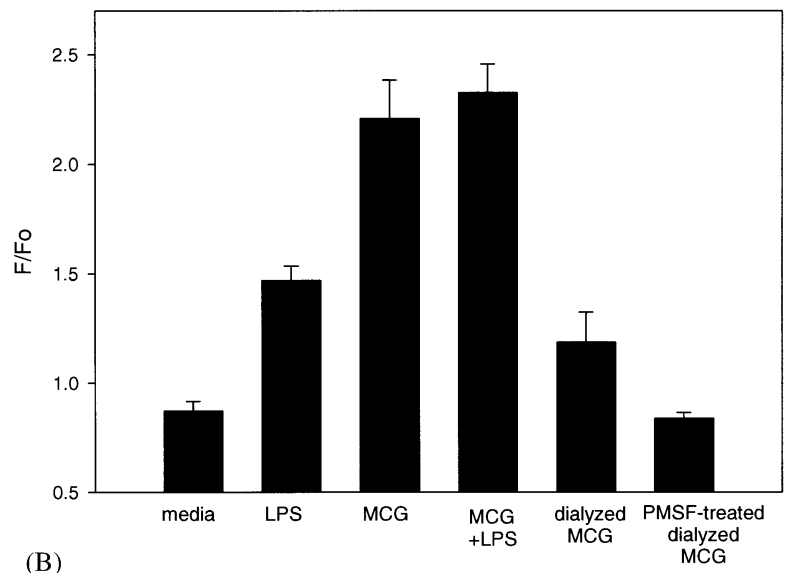

(B)

FIG. 2. (A) Time course of MCG-induced and LPS-induced intracellular $\mathrm{Ca}^{2+}$ levels. Fluo-4-labeled HUVECs $\left(6 \times 10^{5}\right)$ were monitored with confocal microscopy during stimulation with LPS $(100 \mathrm{ng} / \mathrm{ml})$, MCG $\left(3 \times 10^{5}\right.$ mast cell equivalents), and a combination of both agonists (applied at the arrow). The data are plotted as $F / F_{\mathrm{o}}$ as described in the Materials and methods section. The fluorescence values (indicating free intracellular $\mathrm{Ca}^{2+}$ ) increased after the addition of each agonist. Each data point represents the mean \pm standard error of the mean. This is representative of three experiments. (B) MCG-induced and LPS-induced peak transient changes in intracellular $\mathrm{Ca}^{2+}$ levels. Peak $\mathrm{Ca}^{2+}$ transient changes (obtained within 2-4 $\mathrm{min}$ ) were plotted summarizing all experiments. The data are plotted as $F / F_{\mathrm{o}}$ as described in the Materials and methods section. The results presented are from one of three similar experiments using two different fluorophores (calcium crimson and Fluo4) on both a confocal microscope and a SPOT fluorescence microscope. In total, over 150 cells were analyzed for each condition except for dialyzed MCG. Each bar represents the mean \pm standard error of the mean.

of endothelial cells by LPS and MCG (Fig. 3). Incubation of HUVECs with MCG resulted in low level activation of JNK1 between 30 and $60 \mathrm{~min}$, which returned to basal levels by $3 \mathrm{~h}$. Incubation of HUVECs with LPS stimulated peak JNK activity at $3 \mathrm{~h}$, which returned to baseline by $6 \mathrm{~h}$ (data for 1 and $4 \mathrm{~h}$ not shown). However, simultaneous exposure of HUVECs to LPS and MCG prolonged the activation of JNK1 for up to $8 \mathrm{~h}$. The results presented in Fig. 1 and those reported previously ${ }^{10,11}$ demonstrate that both mast cell protease and histamine are involved in MCG-induced endothelial cell activation. Therefore, to further assess the role of proteases and histamine on MCG-induced JNK activation, MCG were incubated with PMSF ( $1 \mathrm{mmol} / \mathrm{l})$ and then subjected to dialysis. The treatment of MCG with PMSF completely inhibited serine protease (chymase) activity, and dialysis depleted the histamine content. As depicted in Fig. 3, the depletion of histamine alone did not affect MCG's ability to induce JNK1 activation. On the other hand, inhibition of protease activity by PMSF treatment abolished the ability of MCG to prolong LPS-induced activation of JNK1.

\section{Effect of MCG on ERK1/2 phosphorylation in HUVECs}

ERK is a recognized signaling pathway in endothelial cell activation. ${ }^{23,24}$ Results presented in Fig. 4 show that MCG stimulated ERK1/2 activation in HUVECs as determined by quantification of p-ERK by western blot. Incubation of HUVECs with MCG at an endothelial cell to mast cell ratio of 2:1 resulted in marked increase in p-ERK at 10 min, which peaked at $30 \mathrm{~min}$ and decreased with time to the basal level within $2 \mathrm{~h}$ (Fig. 4A). As noted in Fig. 4B, the activation of ERK was MCG dose dependent, and plateaued at the endothelial cell to mast cell ratio of 2:1. MCG-induced ERK1/2 phosphorylation was completely blocked by MEK inhibitor PD98059 ${ }^{25}$ at a concentration of $30 \mu \mathrm{mol} / 1$, confirming the involvement of MEK activation (data not shown).

Mast cell granules depleted of both active protease and histamine failed to induce ERK1/2 activation (Fig. $5 \mathrm{~A}$ ). Our previous study has shown that the effect of histamine on endothelial cell production of proinflammatory cytokines is completely abolished by the $\mathrm{H}-1$ receptor antagonist diphenhydramine, but not by the $\mathrm{H}-2$ antagonist famotidine. ${ }^{11}$ To further explore the direct role of histamine in MCG-induced ERK activation in HUVECs, studies were conducted with the $\mathrm{H}-1$ receptor antagonist diphenhydramine. As shown in Fig. 5B, histamine-induced ERK1/2 activation was completely abrogated by diphenhydramine (25 $\mu \mathrm{mol} / \mathrm{l})$, whereas MCG-induced effects were only partially inhibited. These results indicate that both the serine protease and histamine present in MCG are capable of independently activating ERK1/2.

\section{Activation of NF- $\kappa \mathrm{B}$ proteins}

Promoters of the IL-6 gene contain recognition sequences for the transcription factor NF- $\kappa \mathrm{B} .{ }^{26,27}$ EMSAs were carried out using nuclear extracts of HUVECs to examine the effects of MCG and LPS on $N F-\kappa B$ translocation. The exposure of HUVECs to MCG in the presence of LPS for $3 \mathrm{~h}$ substantially increased translocation of $\mathrm{NF}-\kappa \mathrm{B}$ proteins to the 


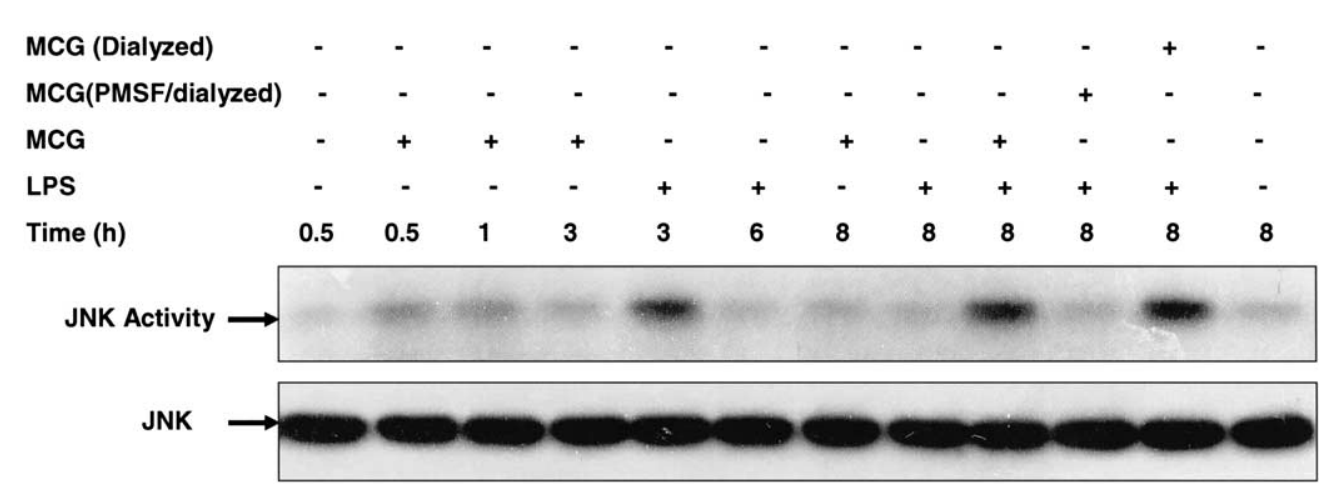

FIG. 3. Kinetics of JNK activation in HUVECs after stimulation with MCG and LPS. Confluent HUVECs $\left(5 \times 10^{6}\right)$ were stimulated with MCG, dialyzed MCG or dialyzed PMSF-treated MCG $\left(2.5 \times 10^{6}\right.$ mast cell equivalents) alone or in a combination with LPS. Cell lysates were prepared after the indicated time intervals. Immune complex kinase assays were performed as described in Materials and methods using GST-c-Jun as a substrate for JNK. Protein loads were monitored by western blot using antiJNK1 antibody. Similar results were noted in two additional experiments.

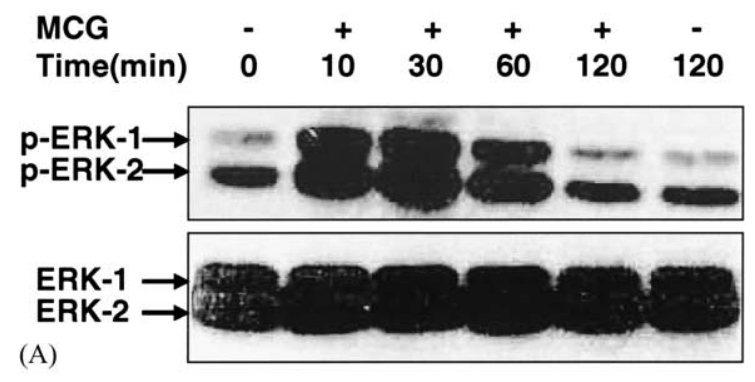

MCG ( $10^{6}$ mast cell equivalent)
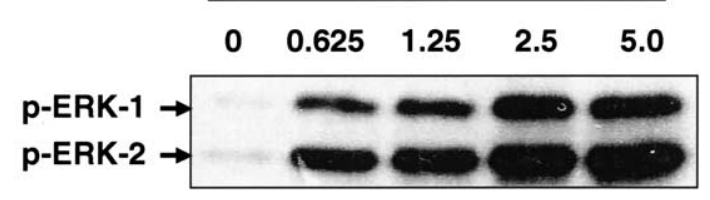

(B)

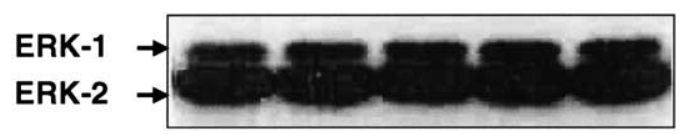

FIG. 4. The kinetics of MCG-mediated ERK1/2 activation in HUVECs. Confluent HUVECs $\left(5 \times 10^{6}\right)$ were treated with MCG $\left(2.5 \times 10^{6}\right.$ mast cell equivalents) for the time intervals indicated $(A)$ or treated with the indicated doses of MCG for $30 \mathrm{~min}$ (B). After treatments, cell lysates were prepared and subjected to SDS-polyacrylamide gel electrophoresis followed by immunoblotting with phospho-specific ERK 1/2 monoclonal antibody. Protein loads were monitored by western blot using ERK1/2 antibodies. Similar results were obtained in three experiments.

nuclei (Fig. 6). The exposure of HUVECs to MCG alone caused an increase in $\mathrm{NF}-\kappa \mathrm{B}$ protein levels in the nuclei, which was of lesser magnitude than that induced by LPS. Both the MCG-induced and LPSinduced NF- $\kappa \mathrm{B}$ translocation returned to baseline by 8 and $16 \mathrm{~h}$, respectively. The augmented levels of nuclear NF- $\kappa \mathrm{B}$ proteins in HUVECs treated with the combination of MCG and LPS decreased gradually but remained elevated throughout the 24-h period.

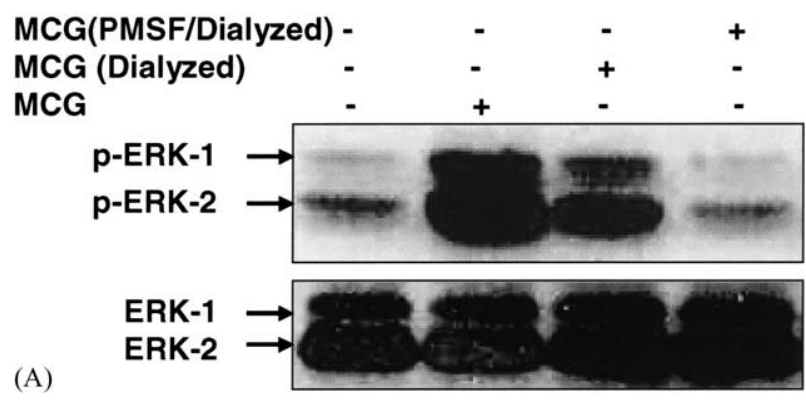

(B)

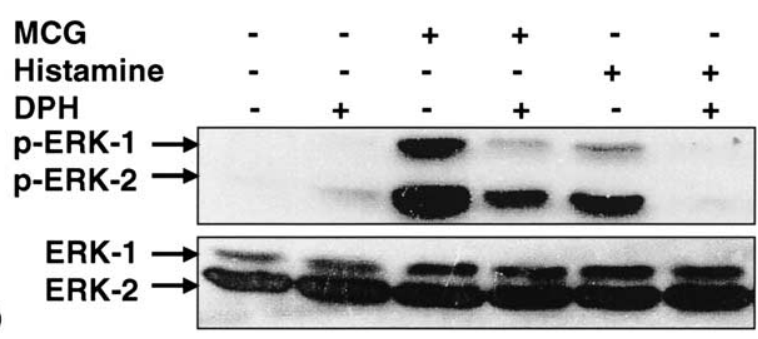

FIG. 5. The involvement of proteases and histamine in MCGinduced activation of ERK1/2. Confluent HUVECs $\left(5 \times 10^{6}\right)$ were incubated with MCG, dialyzed MCG, PMSF-pretreated and dialyzed MCG $\left(2.5 \times 10^{6}\right.$ mast cell equivalents) $(A)$, or with histamine $(25 \mu \mathrm{mol} / \mathrm{l})$ in the absence and presence of diphenhydramine $(25 \mu \mathrm{mol} / \mathrm{l})$ (B) for $30 \mathrm{~min}$. After the treatments, cell lysates were prepared and subjected to SDS-polyacrylamide gel electrophoresis followed by immunoblotting with phospho-specific ERK1/2 monoclonal antibody. Protein loads were monitored by western blot using ERK $1 / 2$ antibodies. Similar results were obtained in three experiments.

\section{Discussion}

Mast cells and their granules contain effector molecules that modulate functions of a variety of cells, including macrophages and endothelial cells. ${ }^{8,9,16,28}$ The results presented here reveal that MCG directly activate human endothelial cells to release low levels of IL-6. The MCG-induced endothelial cell activation was greatly enhanced when HUVECs were simultaneously exposed to LPS. The effect of MCG on 


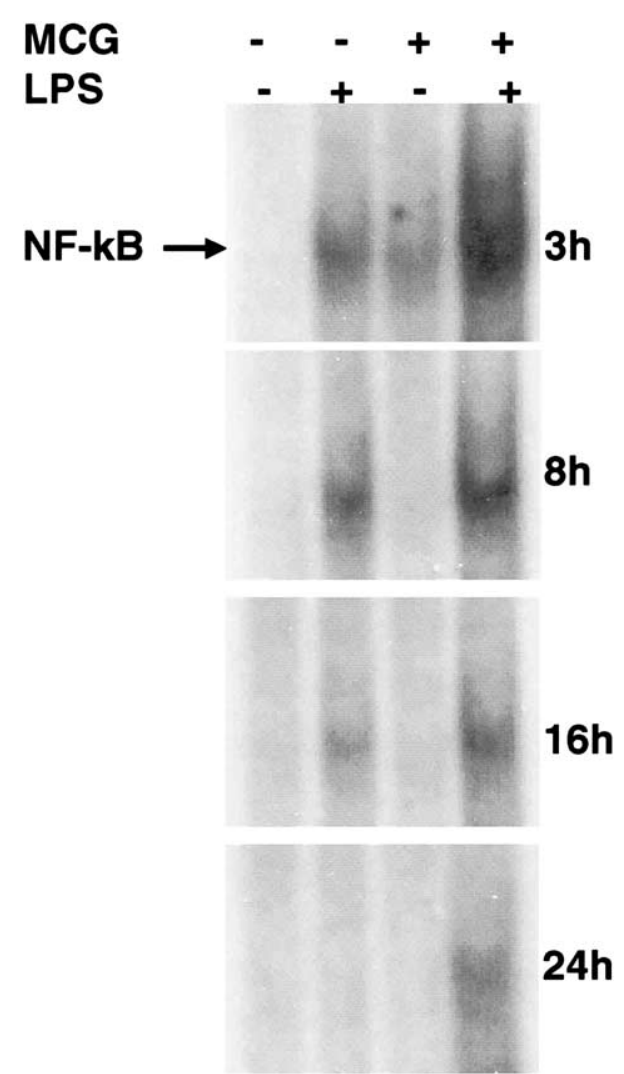

FIG. 6. Electrophoretic mobility shift assay of nuclear NF-kB translocation in HUVECs treated with MCG and LPS. Confluent monolayers of HUVECs $\left(5 \times 10^{6}\right)$ were incubated with MCG $\left(2.5 \times 10^{6}\right.$ mast cell equivalents $)$ in the presence or absence of LPS $(100 \mathrm{ng} / \mathrm{ml})$ at $37^{\circ} \mathrm{C}$ for time intervals as indicated. The nuclear proteins extracted from the cells were incubated with $\gamma-\left[{ }^{32} \mathrm{P}\right]$-labeled oligonucleotide containing NF- $\kappa B$ binding sites. The samples were subjected to electrophoresis on polyacrylamide gels, and the bands were identified by autoradiogragh. The amplification of LPSinduced NF-KB translocation by MCG was also noted in three other experiments.

endothelial cell production of IL- 6 was partially decreased when their histamine content was depleted. On the other hand, when both histamine and serine protease activity were absent, MCG failed to induce endothelial cell activation. These results are in agreement with our previous reports, which demonstrated a significant synergy between MCG and LPS on endothelial cell production of IL- 6 and IL$8,{ }^{8,9}$ and that both histamine and serine proteases present in MCG participate in the induction of cytokine production. ${ }^{9-11}$ The results of the present study demonstrate that the MCG serine proteaseinduced endothelial cell activation involves mobilization of intracellular $\mathrm{Ca}^{2+}$, activation of JNK and ERK1/2, and increased translocation of NF- $\mathrm{KB}$. Histamine independently or when present in the MCG stimulates endothelial cells through the type 1 histamine receptor by increasing intracellular $\mathrm{Ca}^{2+}$ and activating ERK1/2.

Mobilization of $\mathrm{Ca}^{2+}$ is an important event in receptor-mediated activation and involves inositol phosphate turnover and protein kinase $\mathrm{C}$ activation. ${ }^{29}$ Proteases, LPS and histamine are known to induce increases in intracellular $\mathrm{Ca}^{2+30-32}$ Our previous studies with protease activated-receptor agonists demonstrated no correlation between increase in intracellular $\mathrm{Ca}^{2+}$ and the production of IL$6 .{ }^{10}$ In the present study, both MCG and LPS induced comparable changes in intracellular $\mathrm{Ca}^{2+}$, and a combination of these two agonists did not give an additive effect. In contrast, the combination of MCG and LPS synergized endothelial cell cytokine production. ${ }^{89}$ The results suggest that the magnitude of $\mathrm{Ca}^{2+}$ mobilization does not directly relate to the level of endothelial cell cytokine production. It is apparent that both serine proteases and histamine contribute to MCG-mediated increase in intracellular $\mathrm{Ca}^{2+}$.

The MAP kinases, ERK, p38 and JNK, are involved in endothelial activation. ${ }^{20-24}$ The present results demonstrate that MCG-stimulated JNK1 activation in HUVECs occurs within 30-60 min of exposure. The kinetics of JNK1 activation by MCG is distinctly different to that of LPS, which peaked between 1 and $3 \mathrm{~h}$ (data not shown) and dissipated by $6 \mathrm{~h}$. The treatment of HUVECs with a combination of LPS and MCG provided strong and sustained JNK1 activity for up to $8 \mathrm{~h}$, which was not noted with either agonist alone. Pretreatment of MCG with PMSF, the serine protease inhibitor, completely abolished MCG-induced prolongation of JNK1 activity. On the other hand, MCG-induced JNK1 prolongation was unaffected by depletion of histamine from MCG. This was further supported by the finding that histamine neither directly activated nor prolonged LPS-induced JNK1 activation (data not shown). The failure by histamine to induce JNK1 activation is consistent with the lack of JNK activation by histamine in hamster vas deferens smooth muscle cells. ${ }^{33}$ There are two plausible explanations for the sustained JNK1 activation by MCG protease. It has been demonstrated that LPS elevates the expression of PAR-2 on endothelial cells, ${ }^{34}$ and that serine proteases activate PARs. ${ }^{31}$ Therefore, the serine proteases in MCG may activate the newly expressed PARs on HUVECs to induce a second phase of JNK activation. Alternatively, MAP kinase phosphatase-1 (MKP-1) and MKP-2 have been implicated in the termination of JNK activity. ${ }^{35}$ Since MCG are endocytosed by HUVECs, ${ }^{8}$ these organelles containing proteases may inhibit MKP-1 and MKP-2, and permit the prolongation of LPS-induced JNK activation.

Incubation of HUVECs with MCG resulted in significant activation of ERK1/2 in a concentrationdependent and time-dependent manner. The effect of MCG-mediated activation of ERK1/2 was partially abrogated when histamine was depleted or by the addition of $\mathrm{H}-1$ receptor antagonist dyphenhydramine. When MCG preparations were pretreated with PMSF and subsequently dialyzed, ERK1/2 activation 
was blocked. The lack of ERK1/2 activation by protease-free and histamine-free MCG was correlated with the failure to induce IL-6 production and synergize LPS-induced endothelial cell activation. The present result on the effect of histamine on ERK1/2 activation in endothelial cells is consistent with the report by Gudmundsdottir et al. ${ }^{36}$ It is noteworthy that both serine proteases and histamine present in MCG are involved in the activation of ERK1/2, whereas only proteases participate in the activation of JNK. The activation of ERK1/2 by mast cell protease is in agreement with the recent finding of ERK $1 / 2$ activation by tryptase in human eosinophils. ${ }^{37}$ Several reports in the literature implicate LPSinduced ERK1/2 activation in endothelial cells. ${ }^{38-40}$ However, LPS did not activate ERK1/2 in our system and therefore the combined effect of MCG and LPS on ERK1/2 activity was not assessed. The lack of ERK activation by LPS may be explained by the deficiency of soluble CD14 and LPS binding proteins in the 72-h conditioned media that were used in our study to avoid serum-induced spontaneous ERK activation.

A number of studies have demonstrated the role of NF- $\mathrm{KB}$ in the regulation of IL- 6 production. ${ }^{26,27}$ The present study confirms that MCG, containing histamine and serine proteases, cooperate with LPS to synergize NF- $\mathrm{KB}$ translocation in HUVECs. Our previous study also demonstrated that activation of endothelial cells by PAR agonists ${ }^{10}$ and histamine ${ }^{11}$ resulted in NF- $\mathrm{kB}$ translocation, both of which were amplified by LPS. It is apparent that activation of at least two MAP kinase pathways, ERK1/2 and JNK1, are involved in the observed activation of endothelial cells by MCG and LPS. The distinct patterns by which MCG activates JNK1 and ERK1/2 are noteworthy in explaining the synergy between MCG mediators and LPS. Activation of JNK results in enhancement of nuclear c-Jun protein and AP-1 binding, ${ }^{41}$ and augmented formation of c-Jun is known to induce endothelial cell activation. ${ }^{42,43}$ Therefore, the prolonged activation of LPS-induced JNK by MCG is expected to enhance AP-1 binding to the promoters of IL- 6 and IL-8. On the other hand, the direct activation of ERK1/2 by MCG will enhance c-Fos, which in turn can associate with c-Jun to form stable heterodimers $^{44}$ for sustained gene transcription. Thus, the amplification of LPS-induced endothelial cytokine production by MCG may be explained by the coordinated generation of c-Jun and c-Fos, and the enhanced translocation of NF- $\mathrm{KB}$.

In summary, the present study demonstrates that MCG-mediated and LPS-mediated endothelial cell activation utilizes an increase in intracellular $\mathrm{Ca}^{2+}$, translocation of NF-KB, activation of JNK1 and ERK1/ 2 , and that both serine proteases and histamine residing in MCG participate in potentiating the effects of LPS. These findings suggest that the combined effects of MCG mediators and LPS can induce amplified endothelial cell activation. Therefore, mast cell degranulation together with bacterial infection may create a favorable environment for enhanced vascular inflammation.

ACKNOWLEDGEMENTS. This work was supported by grants from the Joseph and Elizabeth Carey Arthritis Funds and the Hinman Fund from the KU Endowment Association, the American Heart Association, and Lied Endowed Basic Science Research.

\section{References}

1. Cotran RS. New roles for the endothelium in inflammation and immunity. Am J Pathol Rev 1987; 129: 407-413.

2. Mantovani A, Sozzani S, Vecchi A, Introna M, Allavena P. Cytokine activation of endothelial cells: new molecules for an old paradigm. Thromb Haemost 1997; 78: 406-414

3. Harlan JM. Leukocyte-endothelial cell interactions. Blood 1985; 65: $513-525$.

4. Vadas MA, Gamble JR, Rye K, Barter P. Regulation of leucocyteendothelial interactions of special relevance to atherogenesis. Clin Exp Pharmacol Physiol 1997; 24: A33-A35.

5. Krishnaswamy G, Kelley J, Johnson D, et al. The human mast cell: functions in physiology and disease. Front Biosci 2001; 1: D1109D1127.

6. Laine P, Kaartinen M, Penttila A, Panula P, Paavonen T, Kovanen PT. Association between myocardial infarction and the mast cells in the adventitia of the infarct-related coronary artery. Circulation 1999; 26: $361-369$.

7. Ihara M, Urata $\mathrm{H}$, Kinoshita $\mathrm{A}$, et al. Increased chymase-dependent angiotensin II formation in human atherosclerotic aorta. Hypertension 1999; 33: 1399-1405.

8. Li Y, Stechschulte AC, Smith DD, Linsley HB, Stechschulte DJ, Dileepan KN. Mast granules potentiate endotoxin induced interleukin- 6 production by endothelial cells. J Leukoc Biol 1997; 62: 210-216.

9. Jehle AB, Li Y, Stechschulte AC, Stechschulte DJ, Dileepan KN. Endotoxin and mast cell granule proteases synergistically active human coronary artery endothelial cells to generate interleukin- 6 and interlaukin-8. J Interferon Cytokine Res 2000; 20: 361-368.

10. Chi L, Li Y, Stehno-Bittel L, Gao JJ, Morrison DC, Stechschulte DJ, Dileepan KN. Interleukin-6 production by endothelial cells via stimulation of protease-activated receptors is amplified by endotoxin and tumor necrosis factor- $\alpha$. J Interferon Cytokine Res 2001; 21: 231-240.

11. Li Y, Chi L, Stechschulte DJ, Dileepan KN. Histamine-induced production of interleukin- 6 and interleukin- 8 by human coronary artery endothelial cells is enhanced by endotoxin and tumor necrosis factora. Microvascular Res 2001; 61: 253-262.

12. Himmel HM, Whorton AR, Strauss HC. Intracellular calcium, currents, and stimulus-response coupling in endothelial cells. Hypertension 1993; 21: $112-127$.

13. Aggarwal BB. Tumor necrosis factors receptor associated signaling molecules and their role in activation of apotosis, JNK, and NF- $\mathrm{KB}$. Ann Rheum Dis 2000; 59(suppl): i6-i16.

14. Brand K, Page S, Walli AK, Neumeier D, Baeuerle PA. Role of nuclear factor- $\mathrm{\kappa B}$ in atherogenesis. Exp Physiol 1997; 82: 297-304.

15. Jersmann HP, Hii CS, Ferrante JV, Ferrante A. Bacterial lipopolysaccharide and tumor necrosis factor alpha synergistically increase expression of human endothelial adhesion molecules through activation of NFkappaB and p38 mitogen-activated protein kinase signaling pathways. Infect Immun 2001; 69: 1273-1279.

16. Dileepan KN, Lorsbach RB, Stechschulte DJ. Mast cell granules inhibit macrophage-mediated lysis of mastocytoma cells (P815) and nitric oxide production. J Leukoc Biol 1993; 53: 446-453.

17. Schwartz LB, Irani AM, Roller K, Castells MC, Schechter NM. Quantitation of histamine, tryptase and chymase in dispersed human $\mathrm{T}$ and $\mathrm{TC}$ mast cells. J Immunol 1987; 138: 2611-2615.

18. Muroi M, Muroi Y, Yamamoto K, Suzuki T. Influence of $3^{\prime}$ half-site sequence of NF-кB motifs on the binding of lipopolysaccharideactivatable macrophage NF- $\mathrm{KB}$ proteins. J Biol Chem 1993; 268: $19534-19540$.

19. Muroi M, Muroi Y, Suzuki T. The binding of immobilized IgG2a to Fck2a receptor activates $\mathrm{NF}-\mathrm{\kappa B}$ via reactive oxygen intermediates and tumor necrosis factor. J Biol Chem 1994; 269: 30561-30568.

20. Potente M, Michaelis UR, Fisslthaler B, Busse R, Fleming I. Cytochrome P450 2C9-induced endothelial cell proliferation involves induction of mitogen-activated protein (MAP) kinase phosphatase-1, inhibition of the c-Jun N-terminal kinase, and up-regulation of cyclin D1. J Biol Chem 2002; 277: $15671-15676$.

21. Zhang C, Kawauchi J, Adachi MT, Hashimoto Y, Oshiro S, Aso T, Kitajima S. Activation of JNK and transcriptional repressor ATF3/LRF1 through the IRE1/TRAF2 pathway is implicated in human vascular 
endothelial cell death by homocysteine. Biochem Biophys Res Commun 1994; 289: 718-724.

22. Go YM, Levonen AL, Moellering D, Ramachandran A, Patel RP, Jo H, Darley-Usmar VM. Endothelial NOS-dependent activation of c-Jun NH(2)-terminal kinase by oxidized low-density lipoprotein. Am J Physiol Heart Circ Physiol 2001; 281: H2705-H2713.

23. Kawaguchi M, Onuchic LF, Huang SK. Activation of extracellular signalregulated kinase (ERK) $1 / 2$, but not p38 and c-Jun N-terminal kinase, is involved in signaling of a novel cytokine, ML-1.J Biol Chem 2002; 277: $15229-15232$.

24. Wang Z, Jiang C, Ganther H, Lu J. Antimitogenic and proapoptotic activities of methylseleninic acid in vascular endothelial cells and associated effects on PI3K-AKT, ERK, JNK and p38 MAPK signaling. Cancer Res 2001; 61: 7171-7178.

25. Cuenda A, Alessi DR. Use of kinase inhibitors to dissect signaling pathways. Methods Mol Biol 2000; 99: 161-175.

26. Shimuzu H, Mitomo K, Watanabe T, Okamoto S, Yamamoto K. Involvement of NF- $\mathrm{KB}$ in the activation of IL- 6 gene by inflammatory lymphokines. Mol Cell Biol 1990; 10: 561-568.

27. Liberman TA, Baltimore D. Activation of interleukin 6 gene expression through the NF- $\mathrm{KB}$ transcription factor. Science 1988; 242: 540-546.

28. Dileepan KN, Simpson KM, Stechschulte DJ. Modulation of macrophage superoxide-induced cytochrome c reduction by mast cells. J Lab Clin Med 1989; 113: $577-585$

29. Berridge MJ, Lipp P, Bootman MD. The versatility and universality of calcium signaling. Nat Rev Mol Cell Biol 2000; 1: 11-21.

30. Umans JG, Salvi D, Murray PT, Wylam ME. Selectivity of endotoxininduced defect in endothelial calcium mobilization. Kidney Int 1998; 54 1063-10639.

31. Molino M, Marilyn J, Woolkalis JM, et al. Endothelial cell thrombin receptors and PAR-2: two protease-activated receptors located in a single cellular environment. J Biol Chem 1997; 272: 11133-11141.

32. Worthen LM, Nollert MU. Intracellular calcium response of endothelial cells exposed to flow in the presence of thrombin or histamine. $J$ Vasc Surg 2000; 32: 593-601.

33. Robinson AJ, Dickenson JM. Activation of the p38 and p42/p 44 mitogenactivated protein kinase families by the histamine $\mathrm{H}(1)$ receptor in DDT(1)MF-2 cells. Br J Pharmacol 2001; 133: 1378-1386.

34. Nystedt S, Ramakrishnan V, Sundelin J. The protease-activated receptor2 is induced by inflammatory mediators in human endothelial cells. $J$ Biol Chem 1996; 271: 14910-14915.
35. Chu Y, Solski PA, Khosravi-Far R, Der CJ, Kelly K. The mitogen-activated protein kinase phosphatases PAC1, MKP-1, and MKP-2 have unique substrate specificities and reduced activity in vivo toward the ERK2 sevenmaker mutation. J Biol Chem 1996; 271: 6497-6501.

36. Gudmundsdottir IJ, Halldorsson H, Magnusdottir K, Thorgeirsson G. Involvement of MAP kinases in the control of CPLA(2) and arachidonic acid release in endothelial cells. Atherosclerosis 2001; 156: 81-90.

37. Temkin V, Kantor B, Weg V, Hartman ML, Levi-Schaffer F. Tryptase activates the mitogen-activated protein kinase/activator protein-1 pathway in human peripheral blood eosinophils, causing cytokine production and release. J Immunol 2002; 169: 2662-2669.

38. Arbabi S, Carcia I, Bauwer G, Maier RV. Hypertonic saline induces prostacyclin production via extracellular signal-regulated kinase (ERK) activation. J Surg Res 1999; 83: 141-146.

39. Arbabi S, Rosengart MR, Garcia I, Maier RV. Hypertonic saline solution induces prostacyclin production by increasing cyclooxygenase-2 expression. Surgery 2000; 128: $198-205$.

40. Schumann RR, Pfeil D, Lamping N, et al. Lipopolysaccharide induces the rapid tyrosine phosphorylation of the mitogen-activated protein kinases erk-1 and p38 in cultured human vascular endothelial cells requiring the presence of soluble CD14. Blood 1996; 87: 2805-2814.

41. Whitmarsh AJ, Davis RJ. Transcription factor AP-1 regulation by mitogen-activated protein kinase signal transduction pathways. $J \mathrm{Mol}$ Med 1996; 74: 589-607.

42. Smalley DM, Lin JH, Curtis ML, Kobari Y, Stemerman MB, Pritchard KA. Native LDL increases endothelial cell adhesiveness by inducing intercellular adhesion molecule-1. Arterioscler Thromb Vasc Biol 1996; 16: $585-590$.

43. Lin JH, Zhu Y, Liao HL, Kobari Y, Groszek L, Stemerman MB. Induction of vascular cell adhesion molecule-1 by low-density lipoprotein. Atherosclerosis 1996; 127: 185-194.

44. Minden A, Lin A, McMahon M, et al. Differential activation of ERK and JNK mitogen-activated protein kinases by Raf-1 and MEKK. Science 1994; 266: 1719-1723.

\section{Received 3 December 2002}

Accepted 15 January 2003 


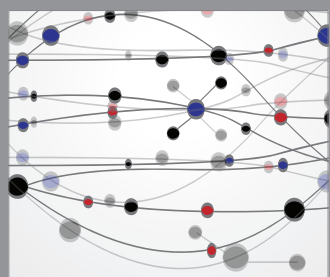

The Scientific World Journal
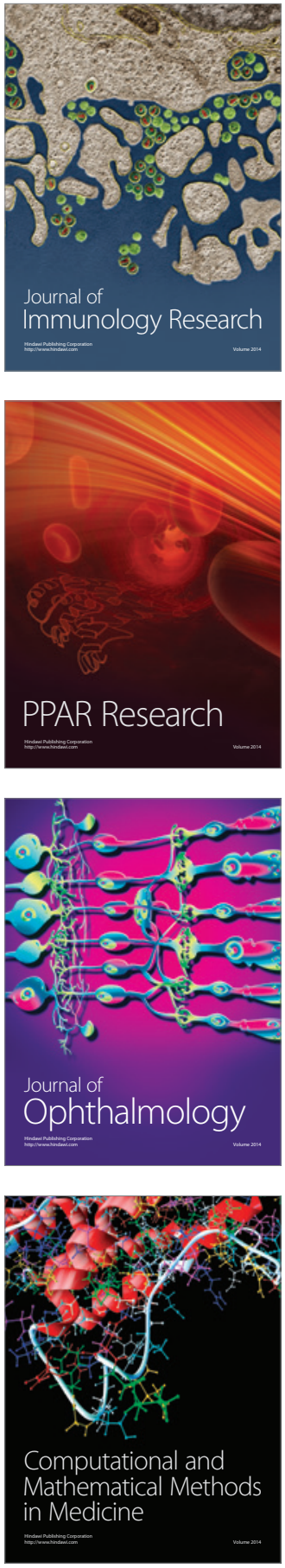

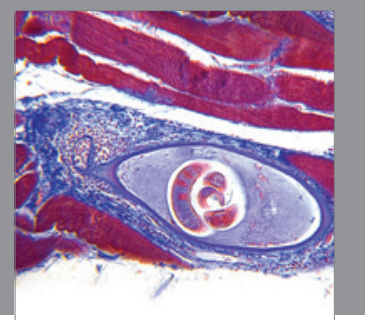

Gastroenterology

Research and Practice
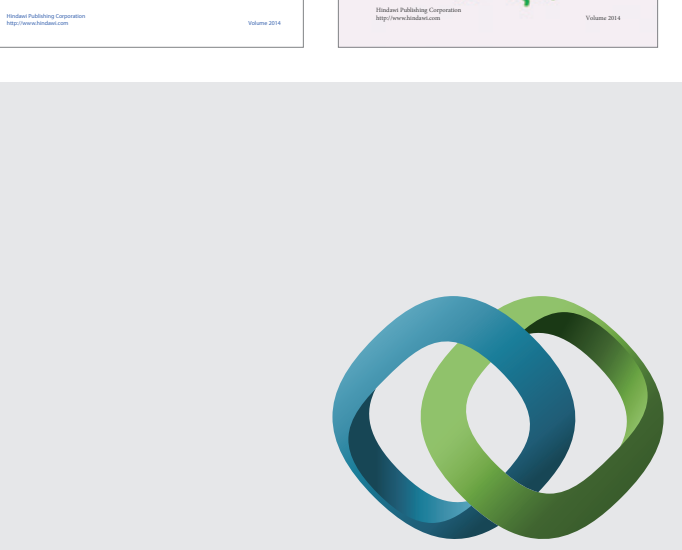

\section{Hindawi}

Submit your manuscripts at

http://www.hindawi.com
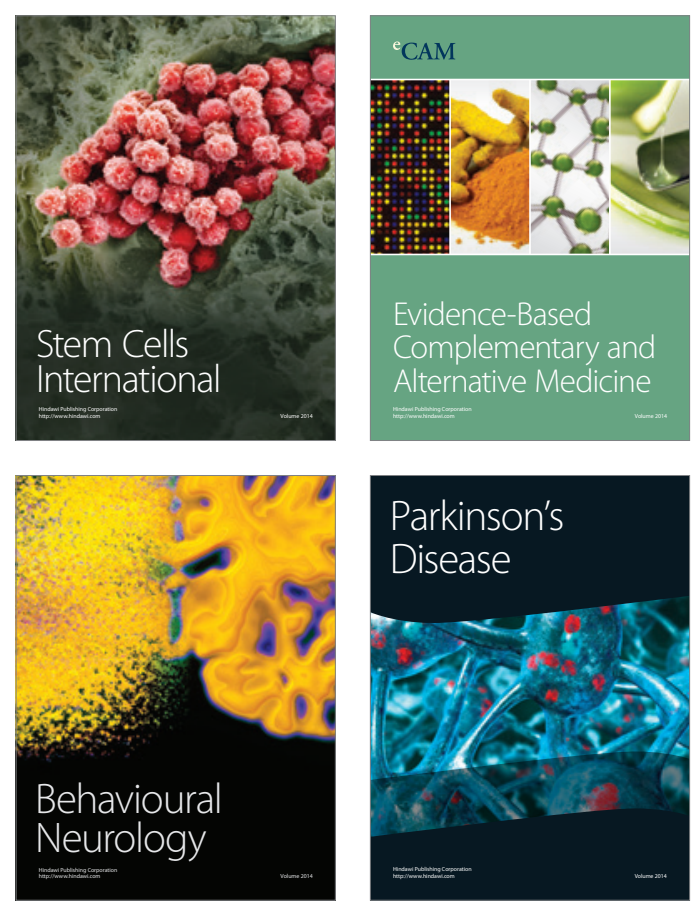

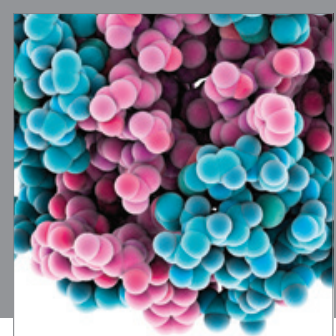

Journal of
Diabetes Research

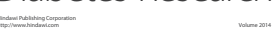

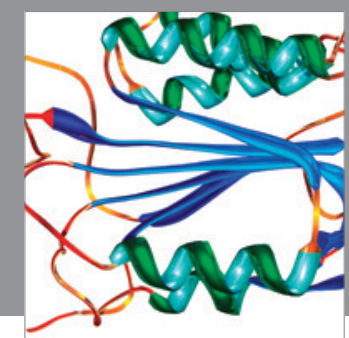

Disease Markers
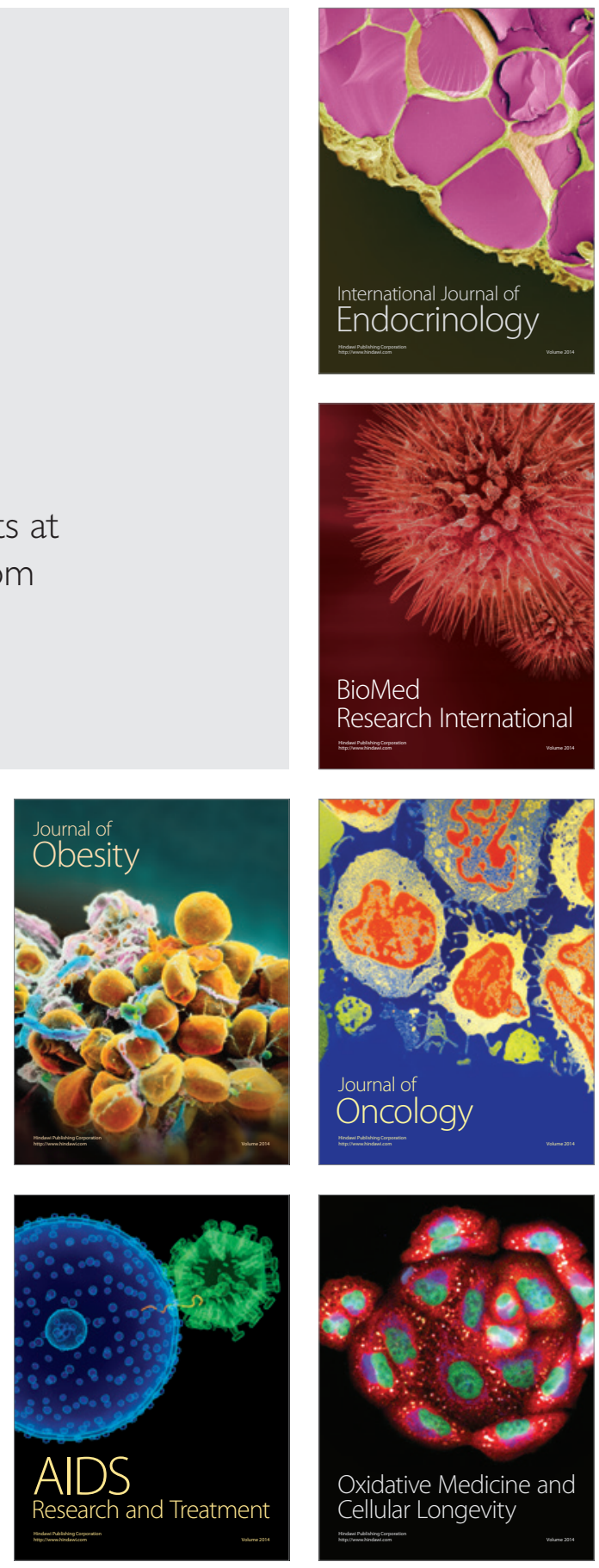